\section{"A Winterized Midget"}

\author{
By RAY PETERSON \\ R.R. 2, Tofield, Alberta
}

It wasn't a likely day to see any bird visitors. The red column in the thermometer had sagged to the thirty below zero mark and stayed there, as though too stiff to ever rise again.

In the lee of a small building, a small huddle of English Sparrows regarded me indifferently. Apparently they were too miserable to bother being cautious. As I stepped into the open-doored shed. a small bird flew from the floor. Promotly, I shut the door to prevent it from escaping.

Clinging to the wall plate in a dim corner was a robin-sized owl. It was a friendly looking little fellow with glass-buttoned eyes that seemed to large for its face. On the floor, from where it had been roused, lay the half-eaten body of an English Sparrow. The plump, little owl wasn't as homeless as its appearance suggested.

I captured the owl quite easily. The small warrior seemed to realize that he was at my mercy, for a time at least, and he submitted without trying to use his formidable claws or strongly-built beak. Defiantly, however, he clacked his bill to let me know that he wasn't afraid of me, not one tiny bit.

Later, Kathryn and I, with "Taverner" playing an oft repeated role, decided that the wee fellow was a Little Boreal Owl.

We would have liked to have kept the little owl. He was such a bold, handsome fellow. Fortunately, better nature prevailed. After learning his identity, we turned him free. He will be remembered, though, for he brought a wealth of interest and enjoyment on a day that had begun coldly barren.

\section{EXCHANGE OF SPECIMENS INVITED}

Anyone interested in exchanging insect specimens - especially butterflies and moths?

Will buy or trade material in these groups as preferred. Particularly interested in moths.

\section{Winter's Perfume}

Elizabeth Cruickshank

On a brittle cold day I raised the cover of my little terrarium in the south window. As if by magic I was no longer house-weary. The fragrance of the plants in the soft moist earth had carried me on a long-ago quest. for my fern collection. Through dim woods and tall brake we had come to the shady cliff where tre sensitive fern grew in abundance, while far below on the bank of the clear little brook the dainty fragile fern enjoyed life in such a happy environment.

No other sense, says Maeterlinck, possesses such an after-call as the sense of smell. "Sight preserves pictures, but it is photographic and exclusive. Hearing deals in echoes, but smell will recreate in a way almost miraculous the inner emotion of a particular time and place."

How often we have heard the phantom music of the clover fields of home carried on a fragrant breeze. My wee bit of confined earth had put my feet on springy ground. If we cannot have the field we may in memory enjoy its wealth for the healing and comfort that "fulfils our hourly need. the daily manna gives."

On a brilliant day in late November a drive to Long Lake was an experience to remember. Uplifted as in a glory by the panorama before us-the sky such rich vivid blue high above, paler graded blue to cool green below, I felt how thankful we should be for eyes to thrill to the "fine" sincerity of light and the luxury of open sky"; and the lake, ice-sealed, a valley paved with stars: paths across its milky ways in a glistening world.

Single duck tracks showed a lone bird's travels to reach open water. Muskrats, warmly red, sunned themselves undisturbed by our nearness. Far below the surface of the melted ice, near the shore, busy water bugs swam. Chickadees flitted about in the overhanging willows. "Oh, for the gift to crystallize the rich simplicity of rhythm in the woods and sky, in songs as free as-chickadee."

Caught up in the spell of the perfume of winter distilling about us from sun-drenched sodden grass, (Continued on Page 7) 
wings, and looking up, saw a Ruffed Grouse fleeing in panic before a Pigeon Hawk - about twenty yds. behind him. The grouse landed on the ground and the falcon landed in a tree above him and waited in ambush. A shot, fired at him, soon changed his mind.

THE SPARROW HAWK - feeds on mice and insects. These birds will often so gorge themselves on mice that they will sit droopily in trees for hours while digestion does its work. Only rarely do they catch sparrows.

The diet of the GREAT HORNED OWL is said to be one-third birds, the rest mammals. However, I believe this is not true, but that about one-third of these birds have acquired a.taste for birds, while the others seldom touch them. One nest, we found, contained the nest of several rats, another contained the remains of varying Hares. In neither case was an incriminating feather found.

Once Great Horned Owls have acquired the taste for birds - guard your poultry. They will even kill geese and turkeys. Once we came upon a Great Horned Owl eating a Short-eared Owl. Such a cannibal! However, let's make sure of a Great Horned Owl's diet before we shoot him. It may cost you a hen, but what is that compared with innumerable rats and mice?

The SNOWY OWL - feeds on mice and hares, and also takes some game birds.

The SHORT-EARED OWL feeds almost entirely on mice. One day I saw a cat carrying a mouse, with an immature Short-eared Owl hovering low over his back and looking hungrily down at him with big, greedy eyes. He followed the cat up the lane and right to the house.

THE LONG-EARED OWL feeds mostly on mammals. Immature ones sometimes kill poultry.

Our hawks and owls are mostly beneficial, so let us do our best to protect them. Their destruction results in an upset in the balance of nature, so that there is an over abundance of mammalian pests, resulting in much destruction to our crops.

\section{The Chickadee}

John E. Nixon, Wauchope, Sask.

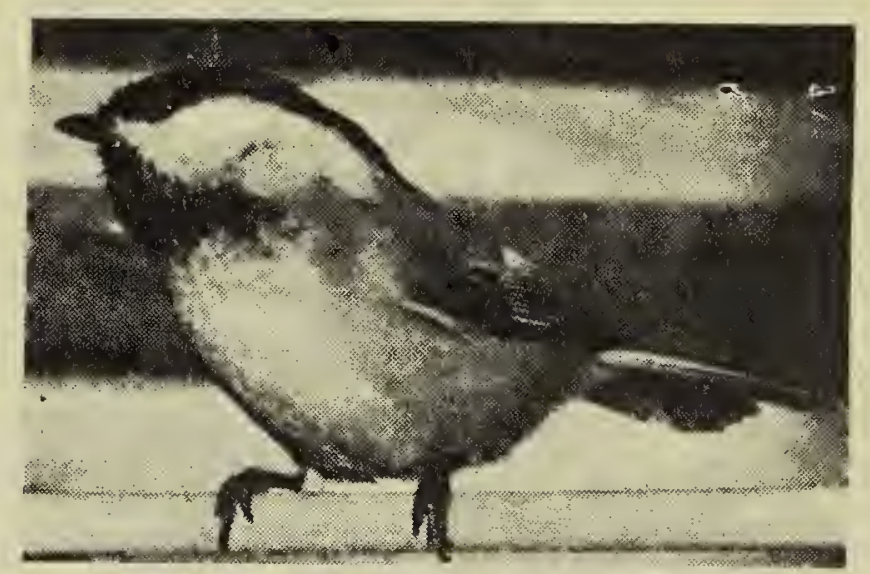

When all the world is robed in white

Then often comes a friendly sprite Among the leafless trees.

A black-capped, cheery little soul, Flitting about each bough and bole Completely at his ease.

Careless of wind or frost or snow, I see him gaily come and go A spirit of the groves.

The storms of winter try him not; Contented with his humble lot In merry mood he roves.

He seems to seek the ways I tread, And by my side, or overhead,

He gladly calls to me

With that clear note that loud and sweet

The silent winter woods repeat

Of chick-a-dee-dee-dee.

From bough to bough he quickly wings

Or to a nodding grass stem clings, Audacity itself.

Less dreary are these winter days For his confiding, friendly way,

The fearless, feathered elf!

WINTER'S PERFUME - 13-14MB (Continued from Page 2)

dead dank leaves, wet logs, we felt, strangely, a sea - weed - laden breeze from Fundy Bay and were once again breathing deep the salty air. Emotions provoked by smell, how real and lasting.

A bush rabbbit hurrying past a rose bush on the bank - the fat crimson haws gleaming, making a patch of splendor in the snow, brought us back to the present. But the glorious scene and the fragrance of this day would be recalled again and again.

"Remembered joys are never past,

They were, they are, they yet shall be." 